\title{
The Generation of Transgenic Mice with Fat1 and Fad2 Genes that have their own Polyunsaturated Fatty Acid Biosynthetic Pathway
}

\author{
Yue Chen a,e Mei Meibe Peng Zhang ${ }^{\mathrm{a}}$ Kuiying Ma ${ }^{\mathrm{a}}$ Guangqi Songa Xin Mac \\ Tianchuang Zhao ${ }^{\mathrm{a}}$ Bo Tang ${ }^{\mathrm{a}}$ Hongsheng Ouyang ${ }^{\mathrm{a}}$ Guangpeng Li $^{\mathrm{d}}$ Ziyi Li $^{\mathrm{a}}$ \\ ajilin Provincial Key Laboratory of Animal Embryo Engineering, the Center for Animal Embryo \\ Engineering of Jilin Province, College of Animal Science and Veterinary Medicine, Jilin University, \\ Changchun, Jilin, China; ${ }^{b}$ Heping Campus Hospital, Jilin University, Changchun, Jilin, China; 'College of \\ Animal Science and Technology, Jilin Agricultural University, Changchun, Jilin, China; ${ }^{\mathrm{d} T h e}$ center for \\ experimental animal research, Inner Mongolia University, Hohhot, Inner Mongolia, China; ${ }^{\mathrm{e} C o n t r i b u t e d}$ \\ equally to this work
}

\section{Key Words}

Polyunsaturated fatty acids (PUFAs) - Omega-3 PUFAs • Omega-6 PUFAs • Fat-1 • Fad-2 • Transgenic mice

\begin{abstract}
Background: Microorganisms and higher plants possess their own omega- 3 and omega- 6 polyunsaturated fatty acid (PUFAs) biosynthetic pathways. The $n-6$ fatty acid desaturase gene fad- 2 codes for the $n-6$ desaturase enzyme that coverts oleic acid (OA 18:1 n-9) into linoleic acid (LA 18:2 n-6). The $n-3$ fatty acid desaturase gene fat- 1 codes for the $n-3$ desaturase enzyme that converts $n-6$ PUFAs into n-3 PUFAs. Mammals lack $n-3$ and $n-6$ desaturase enzymes; therefore, they must obtain their omega- 3 and omega- 6 fatty acids by consuming plants or seafood. The beneficial effects of n-3 and n-6 PUFAs on human development and cardiovascular health have been well documented. Methods: Here, we generated fat- 1 and fad-2 transgenic mice by introducing mammal expression vectors containing the fat- 1 and fad-2 genes via microinjection. Results: Seven transgenic mice were obtained that expressed functional $n-3$ and $n-6$ desaturase enzymes. Analysis of the fatty acid contents of transgenic mouse livers revealed that $n-6$ and n-3 PUFA levels were greatly increased in the transgenic mice compared to wild-type mice. The use ratios of n-9 PUFAs (18:1 n-9) and n-6 PUFAs were both greater in the transgenic mice than in the wild-type controls. Conclusion: These transgenic mice were capable of producing their own omega- 3 and omega- 6 fatty acids. They have the same fatty acid metabolic pathways as higher plants and microbes.
\end{abstract}


Chen et al.: Transgenic Mice with Fat1 and Fad2 Genes

\section{Introduction}

Microorganisms and plants have their own omega- 3 and omega-6 PUFA biosynthetic pathways [1]. The n- 6 desaturase enzyme, coded by the fad-2 gene, introduces a double bond at position $\Delta 12$ to convert oleic acid (OA 18:1 n-9) into linoleic acid (LA 18:2 n-6). The n-3 desaturase enzyme, coded by the fat-1gene, introduces a double bond at position $\Delta 15$ to covert linoleic acid (LA 18:2 n-6) to $\alpha$-linolenic acid (ALA 18:3 n-3). The n-3 desaturase enzymes have broad omega- 6 PUFA substrate specificity, allowing them to convert $\gamma$-linolenic acid, di-homo- $\gamma$-linolenic acid, and arachidonic acid into eicosapentaenoic acid (EPA 20:5 n-3), docosapentaenoic acid (DPA 22:5 n-3), and docosahexaenoic acid (DHA 22:6 n-3), respectively. C. elegans is a good model in this respect because it is an animal that possesses an n-3 desaturase activity. Their n-3 desaturase enzymes elaborate a wide range of n-3 PUFAs including arachidonic and eicosapentaenoic acids [2-4]. The n-6 PUFAs and $n-3$ PUFAs are typified by linoleic acid (LA) and $\alpha$-linolenic acid (ALA), respectively. Both ALA and LA are metabolised to longer-chain PUFAs, primarily in the liver.

Omega-3 and omega-6 PUFA biosynthetic pathways do not occur in mammals; therefore, mammals must obtain omega- 3 and omega- 6 PUFAs from their diets [5]. Linoleic acid (LA 18: $2 \mathrm{n}-6$ ) and $\alpha$-linolenic acid (ALA 18: $3 \mathrm{n}-3$ ) are essential fatty acids that are required for normal growth in mammals. These PUFAs are integral components of cell membranes. They also play important roles in determining the structures of the eicosanoids that regulate the release of hypothalamic and pituitary hormones [6]. Furthermore, highly unsaturated PUFAs, such as arachidonic acid, docosatetraenoic acid, and docosahexaenoic acid, are found in high concentrations in the structural lipids of the central nervous system and are essential in infant nutrition $[7,8]$. C. elegans mutants lacking fatty acid desaturase genes have PUFA deficiencies that cause growth and neurological defects, such as slow growth, abnormal body shape, sluggish movement, cuticle defects, and reduced brood size [9] .

Saeki et al. generated transgenic pigs that carried the fad-2 gene for n- 6 fatty acid desaturase from spinach. Adipocytes differentiated in vitro from the transgenic pigs had higher LA levels [10]. Kang et al. generated healthy humanised transgenic mice expressing the fat-1 gene (hfat-1) with the n-3 fatty acid desaturase from $C$. elegans. These transgenic mice produced significantly more $n-3$ fatty acids and had a reduced $n-6 / n-3$ ratio compared with wild-type mice [11]. The transgenic mice also had significantly elevated n-3 fatty acid levels in their milk. Neonatal mice fed with milk from transgenic mothers had increased levels of docosahexaenoic acid (DHA) in their brain tissue $[12,13]$. Lai et al. reported that expression of $h f a t-1$, encoding the n-3 fatty acid desaturase from C. elegans, significantly increased the n-3 fatty acid content and sharply decreased the ratio of n- $6 / n-3$ fatty acids in transgenic pigs [14]. Wu et al. generated mfat- 1 transgenic cattle that had significantly reduced n-6/n-3 ratios in both their tissue and milk [15]. Endogenous production of n-3 and n-6 fatty acids in mammalian cells has also been described [16]. Other reports have shown that fatty acid desaturase genes isolated from higher plants, such as maize [17], spinach [10], and scarlet weeds [18],function well in mammals after being introduced into animal cells.

However, at present, there are no mammal systems that possess both omega- 3 and omega-6 PUFA biosynthetic pathways. Here, we report the production of transgenic mice that carry cDNA for fad-2 from spinach and fat-1 from C. elegans. These genes were introduced by microinjection of plasmids into fertilised mice eggs. We detected functional expression of the fad-2 and fat-1genes in these transgenic mice and analysed the composition of PUFAs in their livers.

\section{Materials and Methods}

\section{Reagents and animals}

All reagents were purchased from Sigma unless otherwise noted. Kunming (KM) mice and ICR mice were purchased from the Center of Experimental Animals of Jilin University and Changchun Hi-Tech 
Fig. 1. Structure of the expression vector pIRES-FAT1-FAD2. The fat-1 gene was inserted into the pIRES vector using the restriction enzymes XhoI and EcoRI, the vector was then named pIRES-FAT1. Afterwards, the fad2 gene and vector pIRESFAT1were digested by restriction enzymes SalI and NotI, re-ligate to construct the pIRES-FAT1-FAD2 vector.

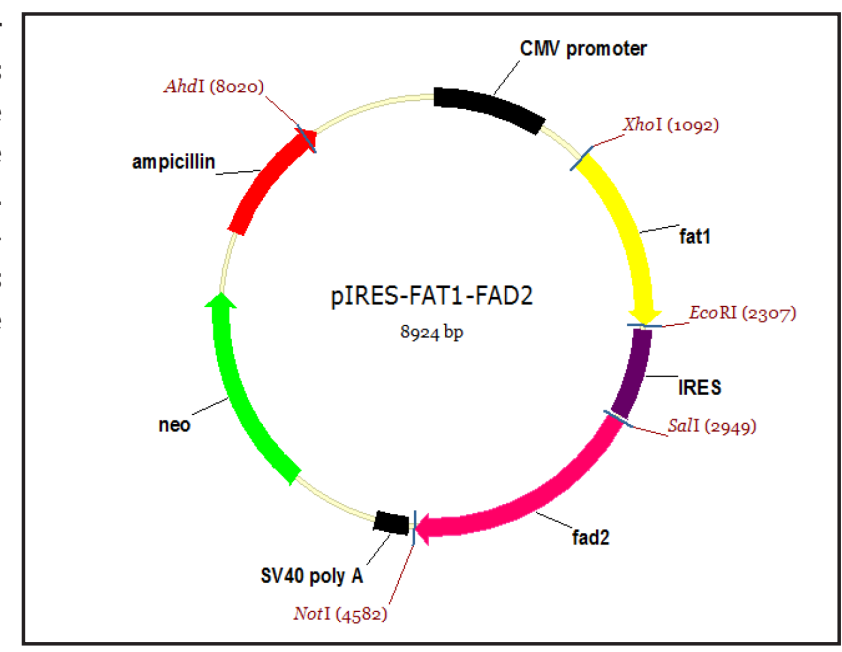

Laboratory Animal Research Center, respectively. The daily diet fed for the mice is a mixture of corn, fishmeal, beans, grain, flour, calcium perphosphate and powder(Nutrition Facts: Protein 18\%, Fat 4\%, Fiber less than 5\%, Powder less than 8\%, Calcium 1-1.8\%, Phosphorus 0.6-1.2\%, Water less than $10 \%$ ). Animals were housed under controlled light cycle $(14 \mathrm{~h} \mathrm{light} / 10 \mathrm{~h}$ dark) conditions. Animal treatments complied with a protocol approved by the Jilin University Institutional Animal Care and Use Committee.

Construction of the fat- 1 and fad-2 expression vector

The coding region of the fat-1 gene from C. elegans (GenBank: NM_001028389) was optimised for mammalian cell expression and introduced into the pIRES expression vector at Xholl and EcoRI restriction sites. The coding region of the fad-2 gene from S. oleracea (GenBank: AB094415.1) was obtained by RTPCR using the following primers: upstream, 5'-ACG CGT CGA CCA CAC TTC GGC CTC TCC TTC TCC TT-3'; and downstream, 5'-AAA AGC GGC CGC AAT TCA CAA ATA ATT GTG TCC CAT-3'. After sequencing, the fad-2 fragment was introduced into the fat-1 expression pIRES-fat1 vector at SalI and NotI restriction sites. The mammalian expression vector containing the fat-1and fad-2 genes was named pIRES-FAT1-FAD2 (Fig. 1).

\section{Generation of transgenic mice}

Six-week-old female ICR mice were superovulated by intraperitoneal injection of 10 IU (international units) of pregnant mare's serum gonadotropin (PMSG, Ningbo, China), followed by intraperitoneal injection of $10 \mathrm{IU}$ of human chorionic gonadotropin (hCG, Ningbo, China) at intervals of $48 \mathrm{~h}$. To generate zygotes, ICR mice were mated with KM (Kunming) male mice at a 1:1 ratio after hCG injection. Females with vaginal plugs were used for zygote preparation. Plugged females were sacrificed at day 0.5 , and the zygotes were collected from their oviducts and denuded from the cumulus cells by treatment with $0.2 \%$ hyaluronidase. For pronuclear microinjection, the pIRES-fat1-fad2 expression vector was excised by digestion with AhdI. The purified transgene was diluted in TE buffer ( 2 to $3 \mathrm{ng} / \mathrm{mL}$ ) and was microinjected into the male pronucleus of zygotes under an inverted microscope (Nikon, Japan). The zygotes were then cultured in $\mathrm{KSOM}$ (Millipore) at $37^{\circ} \mathrm{C}$ in a $5 \% \mathrm{CO}_{2}, 95 \%$ air environment overnight. Embryos at the two-cell stage of development that survived the microinjection were transferred into the oviducts of 0.5 -dpc pseudo pregnant female ICR mice

\section{Transgene detection by RT-PCR}

RT-PCR was carried out to detect the expression of the fad 2 and fat 1 genes in the off spring of the transgenic founders, including both transgenic and wild-type littermates. The total RNA was extracted from tail muscle tissue using the TRIzol Reagent according to the manufacturer's instructions. RNA samples were treated with DNase prior to RT-PCR. Purified RNA (500 ng) was used for first-strand cDNA synthesis. Reverse transcription was performed using oligo-dT primers at $42^{\circ} \mathrm{C}$ for $1 \mathrm{~h}$ and then at $90^{\circ} \mathrm{C}$ for $5 \mathrm{~min}$. The resulting cDNA was used for PCR with primers specific for fad2: upstream, $5^{\prime}$-ACC CAT CCT CTC CAA 
TCT ACT C-3'; and downstream,5'-GTC TTC ATC AGC CTC CAC ATA C-3'. Amplification of the GAPDH gene was used as a control using the following primers: upstream, 5'- ACG TGC CGC CTG GAG AAA CC-3'; and downstream, 5'- GGC CAT GAG GTC CAC CAC CCT G -3'. PCR was carried out by heating at $94^{\circ} \mathrm{C}$ for $5 \mathrm{~min}$; followed by 35 cycles of $94^{\circ} \mathrm{C}$ for $30 \mathrm{~s}, 60^{\circ} \mathrm{C}$ for $30 \mathrm{~s}$, and $72^{\circ} \mathrm{C}$ for $1 \mathrm{~min}$; and a final extension at $72^{\circ} \mathrm{C}$ for $5 \mathrm{~min}$. RNA samples from the muscle tissue of wild-type mice were used as negative controls. Plasmids containing fad 2 fragments were used as positive controls.

\section{Southern blotting analysis}

Genomic DNA $(20 \mu \mathrm{g})$ from the tail tissue of transgenic and non-transgenic mice was digested using HindIII. The digested products were electrophoresed on a $0.8 \%$ agarose gel using TAE buffer and were transferred onto Hybond-N membranes (Invitrogen). Southern blotting was performed using a 479-bp specific hybridisation probe that was labelled with digoxigenin (DIG) using a PCR DIG Probe Synthesis kit (Roche Applied Sciences, Mannheim, Germany). The PCR parameters were as follows: $94^{\circ} \mathrm{C}$ for $5 \mathrm{~min}$; followed by 30 cycles of $94^{\circ} \mathrm{C}$ for $30 \mathrm{~s}, 60^{\circ} \mathrm{C}$ for $30 \mathrm{~s}$, and $72^{\circ} \mathrm{C}$ for $1 \mathrm{~min}$; and a final extension step of $72^{\circ} \mathrm{C}$ for $10 \mathrm{~min}$. The hybridisation probe primer sequences were as follows: upstream, 5' -ACC CAT CCT CTC CAA TCT ACT C-3'; and downstream: 5' -GTC TTC ATC AGC CTC CAC ATA C-3'. Hybridisation and immunological detection were performed according to the instructions provided with the DIG High Prime DNA Labeling and Detection Starter Kit (Roche Applied Sciences, Mannheim, Germany). The positive hybridisation signal was a 3-kb fragment. Genomic DNA from non-transgenic mice was used as a negative control. The pIRESfat1-fad2 plasmid DNA ( $8.9 \mathrm{~kb})$ was used as a positive control.

Integration site analysis in transgenic mice by thermal asymmetric interlaced TAIL-PCR

TAIL-PCR was used to define both the 5' and 3' chromosomal boundaries of the 8.9-kb transgene of the transgenic mice using gene specific primers (GSP) and six arbitrary degenerate primers (AD).

A series of 3 PCR reactions (designated primary, secondary, and tertiary TAIL) were performed. The AD primers were as follows: NGTCGASWGANAWGAA, TGWGNAGSANCASAGA, AGWGNAGWANCAWAGG, STTGNTASTNCTNTGC, NTCGASTWTSGWGTT and WGTGNAGWANCANAGA. The GSPs were 21-24 nucleotides long, with melting temperatures of approximately $64^{\circ} \mathrm{C}$ and GC contents of 50-60\%. The GSPs were as follows: ACCGTACACGCCTACCGCCCATTT, AGGCGCAGACGCAACAGCAAATGC, and GCCAGCCAAGGGTTAGCGTCACAA. The first TAIL-PCR was performed as follows: $94^{\circ} \mathrm{C}(5 \mathrm{~min}), 10$ cycles of $94^{\circ} \mathrm{C}(10 \mathrm{~s}), 64^{\circ} \mathrm{C}(30 \mathrm{~s}), 72^{\circ} \mathrm{C}(3 \mathrm{~min}), 1$ cycle of $94^{\circ} \mathrm{C}(10 \mathrm{~s}), 25^{\circ} \mathrm{C}(3 \mathrm{~min}), 72^{\circ} \mathrm{C}(2.5 \mathrm{~min}), 15$ cycles of $94^{\circ} \mathrm{C}(10 \mathrm{~s}), 64^{\circ} \mathrm{C}(3 \mathrm{~min}), 72^{\circ} \mathrm{C}(2.5 \mathrm{~min}), 94^{\circ} \mathrm{C}(10 \mathrm{~s}), 64^{\circ} \mathrm{C}(3 \mathrm{~min}), 72^{\circ} \mathrm{C}(2.5 \mathrm{~min}), 94^{\circ} \mathrm{C}(10 \mathrm{~s}), 44^{\circ} \mathrm{C}(1 \mathrm{~min})$, and $72^{\circ} \mathrm{C}(2.5 \mathrm{~min})$. Secondary TAIL-PCR was performed as follows: $94^{\circ} \mathrm{C}(5 \mathrm{~min})$, followed by 12 cycles of $94^{\circ} \mathrm{C}(10 \mathrm{~s}), 64^{\circ} \mathrm{C}(3 \mathrm{~min}), 72^{\circ} \mathrm{C}(2.5 \mathrm{~min}), 94^{\circ} \mathrm{C}(10 \mathrm{~s}), 64^{\circ} \mathrm{C}(3 \mathrm{~min}), 72^{\circ} \mathrm{C}(2.5 \mathrm{~min}), 94^{\circ} \mathrm{C}(10 \mathrm{~s}), 44^{\circ} \mathrm{C}(1 \mathrm{~min})$, and $72^{\circ} \mathrm{C}(2.5 \mathrm{~min})$. Tertiary TAIL-PCR was performed as follows: $94^{\circ} \mathrm{C}(5 \mathrm{~min})$, followed by 20 cycles of $94^{\circ} \mathrm{C}(10 \mathrm{~s}), 44^{\circ} \mathrm{C}(1 \mathrm{~min})$, and $72^{\circ} \mathrm{C}(2.5 \mathrm{~min})$.

\section{PUFA analysis}

Male transgenic mice were mated with female C57BL/6 mice to yield non-transgenic and transgenic mice. Six-week-old female offspring were used for PUFA analysis by gas chromatography, as previously described [19]. Fresh mouse liver tissue was homogenised by grinding it in liquid nitrogen, and an aliquot of the tissue homogenate in a glass methylation tube was mixed with $1.5 \mathrm{~mL}$ of hexane and $1.5 \mathrm{~mL}$ of $14 \%$ $\mathrm{BF} 3 / \mathrm{MeOH}$ reagent (Sigma). After blanketing in nitrogen, the mixture was heated at $100^{\circ} \mathrm{C}$ for $1 \mathrm{~h}$ and then cooled down to room temperature; methyl esters were extracted in the hexane phase following the addition of $1.5 \mathrm{~mL}$ of $\mathrm{H}_{2} \mathrm{O}$. The samples were centrifuged at $3000 \mathrm{r} / \mathrm{min}$ for $1 \mathrm{~min}$, and then, the upper hexane layer was removed. Fatty acid methyl esters were analysed by gas chromatography using a fully automated 7890 Network GC System (Agilent Technologies, Palo Alto, CA, USA) equipped with a flame-ionisation detector. Chromatography was performed with an Agilent J\&W fused-silica capillary column (DB-23; $60 \mathrm{~m}, 0.25-\mu \mathrm{m}$ film thickness, 0.25 -mm i.d.; Agilent) . The injector and detector ports were set at $250^{\circ} \mathrm{C}$. FAMEs were eluted using a program held the temperature at $180^{\circ} \mathrm{C}$ for $6 \mathrm{~min}$ and increased by $6.5^{\circ} \mathrm{C} / \mathrm{min}$ to reach $205^{\circ} \mathrm{C}$ for 3 $\mathrm{min}$, before increasing again at $3^{\circ} \mathrm{C} / \mathrm{min}$ to reach $240^{\circ} \mathrm{C}$ for $3 \mathrm{~min}$. The carrier gas was helium at a constant pressure of $230 \mathrm{kPa}$. Peaks were identified by comparison with fatty acid standards. The area percentages for all resolved peaks were analysed using GC ChemStation Software (Agilent Technologies). 
Fig. 2. The selection of transgenic founders by genomic PCR. Left: Detection of fat-1 gene $450 \mathrm{bp}$. M: Marker 2000; 01-05 samples from F0 mice; -: negative control samples from non-transgenic mice; +:positive control samples from expression vector
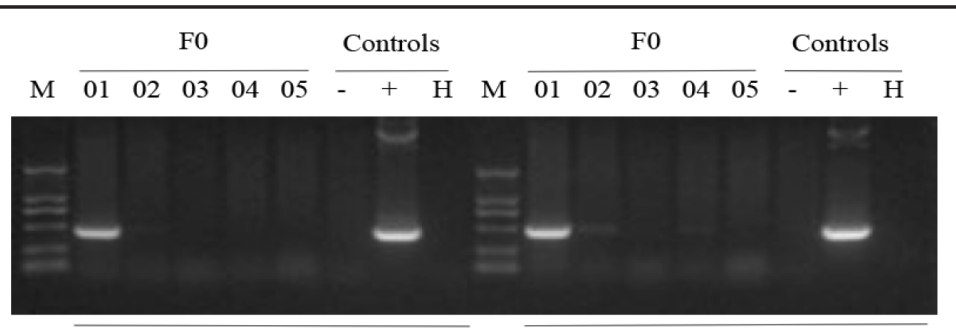

Fat-1

plasmid; H: $\mathrm{ddH}_{2} \mathrm{O}$. Right: Detection of fad-2 gene 479bp. M: Marker2000; 01-05 samples from F0 mice; -: negative control samples from non-transgenic mice; +:positive control samples from expression vector plasmid; $\mathrm{H}: \mathrm{ddH}_{2} \mathrm{O}$.

Fig. 3. The detection of transgenic mice by RT-PCR and Southern blotting. RT-PCR analysis the fad2 cDNA from tail samples of the transgenic mice. The PCR product for fad-2 cDNA is $479 \mathrm{bp}$. GAPDH is the control. The PCR product is 252bp. Southern blotting analysis the transgenic mice. The positive hybridization signal is $3 \mathrm{~kb}$. Positive control is the pIRES-fat1-fad2 vector. Negative control is the genomic DNA of wild type mouse.

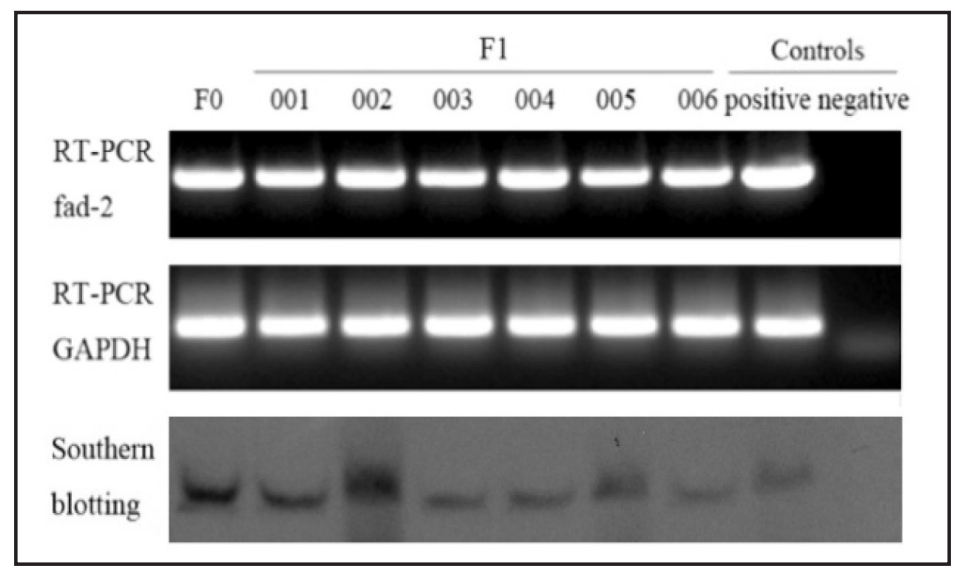

\begin{tabular}{lll}
\hline Mouse & Number of the integration sites & Localization of the integration sites \\
\hline F0 & 4 & chromosome 2, chromosome 7, \\
& & chromosome 3, chromosome 10
\end{tabular}

Table 1. Determination of integration sites and zygosity by Tail-PCR

\section{Results}

Generation of transgenic mice that express both fad-2 and fat-1 genes

The linear transgenic cassettes containing both fad-2 and fat-1 genes were microinjected into the male pronucleii of fertilised eggs that were isolated from super ovulated female mice. Two recipients transferred with a total of 40 embryos became pregnant and gave birth to $5(12.5 \%)$ offspring. PCR analysis of DNA samples from the offspring showed transgenes in one male mouse (Fig. 2). At 6 weeks old, this mouse with transcriptionally active fat-1 and fad-2 was mated with wild-type female mice, producing 6 more offspring. These offspring were all positive by RT-PCR (Fig. 3).

RT-PCR and Southern blotting confirmed the presence of the transgene

RT-PCR analysis of the samples showed the presence of the transgenes in one (F0) and six (F1) mice. To confirm the integration of the transgene, Southern blotting analysis (Fig. 3) was carried out using a fad2 DNA probe designed to hybridise with a 1338bp fragment to demonstrate that all RT-PCR positive mice integrated the transgenes. All 7 founders were fertile and developed into normal adults. 


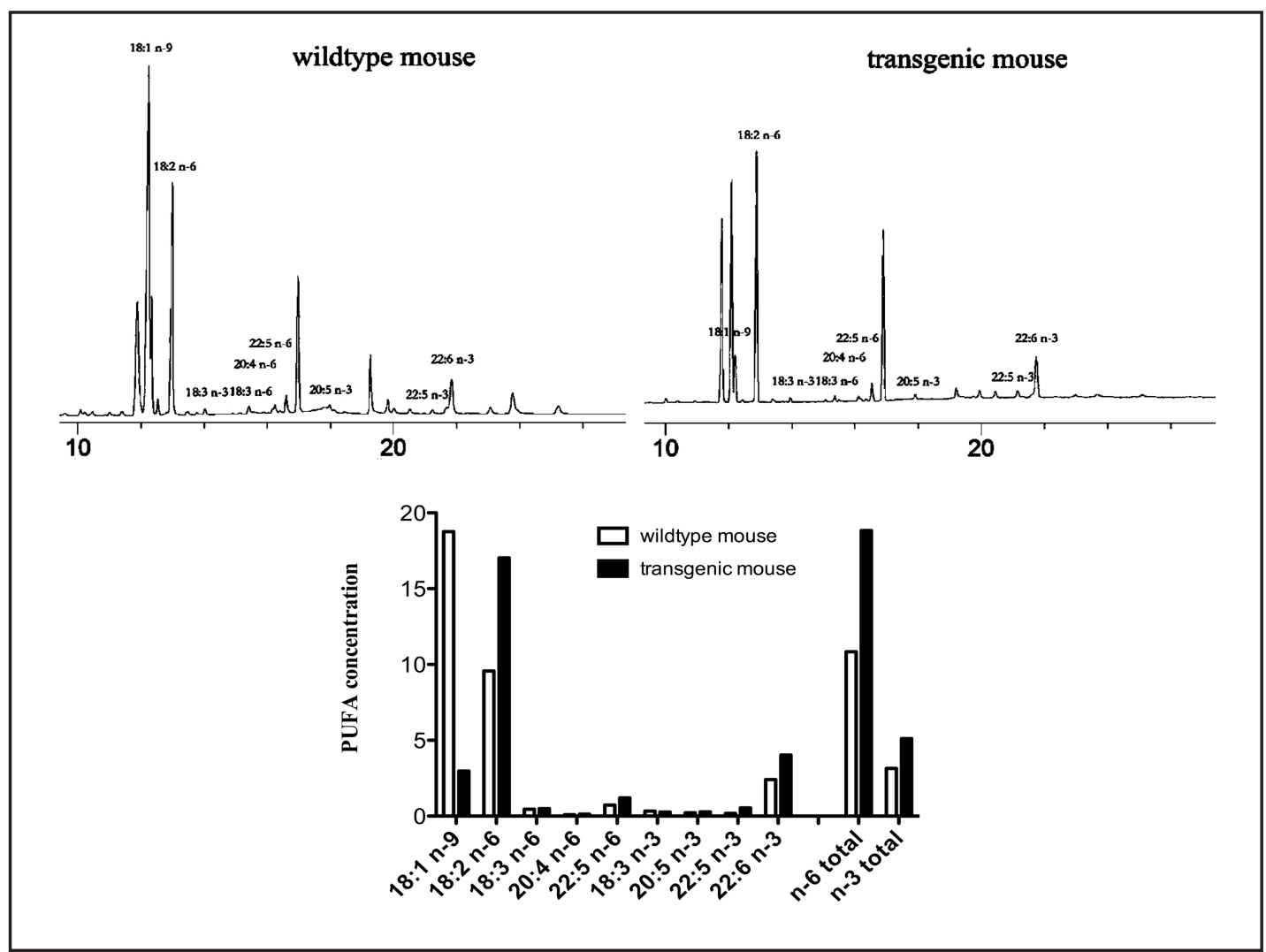

Fig. 4. Functional expression of the fad2 gene and fat1 gene in the F0 transgenic mice.

Table 2. Liver PUFA compositions of F1 transgenic mice and the controls

\begin{tabular}{ccc}
\hline PUFAs & Wildtype mice $(\mathrm{n}=4)$ & Transgenic mice $(\mathrm{n}=6)$ \\
\hline $18: 2 \mathrm{n}-6$ & $10.01 \pm 0.75$ & $16.02 \pm 2.15$ \\
$18: 3 \mathrm{n}-6$ & $0.42 \pm 0.05$ & $0.489 \pm 0.0612$ \\
$20: 4 \mathrm{n}-6$ & $0.09 \pm 0.001$ & $0.12 \pm 0.0198$ \\
$22: 5 \mathrm{n}-6$ & $0.75 \pm 0.08$ & $1.2 \pm 0.159$ \\
$18: 3 \mathrm{n}-3$ & $0.315 \pm 0.0295$ & $0.259 \pm 0.031$ \\
$20: 5 \mathrm{n}-3$ & $0.216 \pm 0.03$ & $0.277 \pm 0.035$ \\
$22: 5 \mathrm{n}-3$ & $0.18 \pm 0.01$ & $0.545 \pm 0.0679$ \\
$22: 6 \mathrm{n}-3$ & $2.39 \pm 0.289$ & $4.1 \pm 0.512$ \\
& & $17.829 \pm 2.39$ \\
$\mathrm{~N}-6$ PUFAs & $10.01 \pm 0.881$ & $5.181 \pm 0.6459$ \\
$\mathrm{~N}-3$ PUFAs & $3.101 \pm 0.3585$ & \\
\hline
\end{tabular}

Tail-PCR to determine integration sites and zygosity

Integration site analysis of the F0 transgenic mouse was performed using TAIL-PCR. There were 4 integration sites found across chromosomes 2, 3, 7, and 10 (Table 1). 


\begin{tabular}{cccc}
\hline & Transgene copy number & Total n-6 PUFAs content & Total n-3 PUFAs content \\
\hline F1-001 & 4 & 18.93 & 5.23 \\
F1-002 & 6 & 15.79 & 4.87 \\
F1-006 & 12 & 16.84 & 5.78 \\
\hline
\end{tabular}

Table 3. Transgene copy number and concentration of PUFAs in F1 transgenic mice

Liver PUFA composition of the transgenic mice

To assess the function of the fat 1 and fad 2 enzymes in the F0 transgenic mouse, the PUFA content in the liver tissue was analysed. As shown in Figure 4, both n-6 and n-3 PUFAs were significantly increased relative to the wild-type values. These data indicate that the fat 1 and fad2 enzymes function in the F0 transgenic mice. For the detailed analysis of fat 1 and fad2 enzyme function, F1 heterozygous transgenic mice and non-transgenic mice were used for PUFA measurement. As shown in Table 2, the concentration of oleic acid (18:1 n-9) was significantly reduced in transgenic mouse liver (3.04 \pm 1.08$)$ compared with the nontransgenic mouse live (19.2 \pm 1.5 ), although the concentrations of linoleic acid (LA 18: $2 \mathrm{n}-6$ ) were not altered $(P>0.05)$ between the transgenic liver $(16.02 \pm 2.15)$ and the non-transgenic liver $(10.01 \pm 0.75)$ (Table 2). Our results indicate that fad-2 is functionally expressed in a complex mammalian system and that fad-2 expression in transgenic mice actively converts oleic acid into LA.

Due to a lack of fat- 1 desaturase, mammals are unable to synthesisen-3 fatty acids. Therefore, they must obtain them from their diet. The $n$-3 fatty acids, including 18:3, 20:5, 22:5, and 22:6, are derived from dietary ALA. Fad-2 and fat-1 expression in transgenic mice promotes de novo biosynthesis of LA and n-3 PUFAs. Therefore, we analysed the n-3 PUFAs, including ALA (18:3 n-3), EPA (20:5 n-3), DPA (22:5 n-3), and DHA (22:6 n-3). As expected, the $n-3$ fatty acid levels in liver tissue from transgenic mice were significantly higher than those in non-transgenic mice. Liver tissue from transgenic mice contained $67.08 \%$ more $n-3$ PUFAs than liver tissue from non-transgenic mice. In addition, the levels of EPA, DPA, and DHA from the transgenic liver tissues increased by $28.24 \%, 202.7 \%$, and $71.55 \%$, respectively.

Transgene copy number and concentration of PUFAs in F1 transgenic mice

To better understand the association between genotype and phenotype, we investigated the relationship between the transgene copy number and the PUFA contents of F1 transgenic mice. As shown in Table 3, there was no direct association between the copy number and the amount of total n-6 and n-3 PUFAs. Different expression levels may be attributed to complex factors, including the genomic context of the gene [20], the transgene methylation status [21], and the transgene copy number.

\section{Discussion}

As we know, the fad 2 and fat 1 desaturase enzymes are the two of the most important fatty acid desaturases. Due to a lack of both of these enzymes, mammals are unable to synthesiseomega- 6 fatty acids and omega- 3 fatty acids; therefore, they must rely obtaining these fatty acids from dietary sources.

Previous studies about PUFAs mainly focused on changing the ratio between $n-3$ fatty acids and n- 6 fatty acids in diets to improve health $[1,22]$. Such studies might yield conflicting results due to the inevitable variance in the dietary composition and eating habits of humans and animals [23]. In our fad 2 and fat 1 transgenic mice, the fad 2 desaturase enzymes promoted de novo biosynthesis of $n-6$ PUFAs, and the fat 1 desaturase enzymes converted the n-6 PUFAs into n-3 PUFAs. We analysed the oleic acids, LA and ALA, as well as 
downstream $n$-3 fatty acids, including EPA, DPA, and DHA. Livers from transgenic mice had higher levels of both n- 6 and n-3 PUFAs than controls, suggesting that our transgenic mice can synthetise omega- 3 and omega- 6 PUFAs. These mice have the same fatty acid metabolic pathways as higher plants and microbes.

In general, vegetable oils, beef, and chicken contain high levels of $n-6$ fatty acids, whereas fish oils contain high levels of $n-3$ fatty acids. The modulation of fatty acid content by inducing the expression of foreign desaturase genes in transgenic animals might reveal the effect that fatty acids have on the body $[16,24]$. Transgenic animal models expressing plant fad2 genes have been generated $[10,25]$. Furthermore, $n-6$ fatty acids have been indicated in several diseases, such as hyperinsulinism, arteriosclerosis, and cancer [26-29]. Transgenic animal models expressing the $C$. elegans fat- 1 gene have also been generated $[11,14,30]$. The fat-1 transgenic mice have now been widely used to study the effects of fatty acids on various health conditions [31-35]. PUFAs serve as signalling molecules and as precursors for other signalling molecules, such as prostaglandins, leukotrienes, and thromboxanes, and can exert a wide range of biological effects. Deficiencies in $n-6$ or $n-3$ PUFAs may cause different symptoms in mammals. A lack of $n$-3 PUFAs results in nervous system disease, whereas a lack of $n-6$ PUFAs results in non-neuronal abnormalities, including reduced growth, reproductive failure, skin lesions, fatty liver, and polydipsia [36]. Due to the importance of both n-6 and n-3 PUFAs, monitoring both the ectogenic balance of $n-3 / n-6$ ratios and the endogenic synthetic amounts of $n-6$ and $n-3$ could be important.

Our transgenic mice, which express both fad 2 and fat 1 desaturase enzymes, have their own PUFA biosynthetic pathways. In the future, we will continue to work on improving the endogenic balance of n-3 and n-6 PUFAs. In addition to the fad 2 transgenic mice created by Chen et al. [25] and the fat1 transgenic mice created by Kang et al [11], the fad2 and fat1 transgenic mice we produced may represent an opportunity to further study the various diseases caused by deficiencies in n- 6 and n-3 PUFAs. Furthermore, the fad 2 and fat 1 transgenic animals may serve as references for the commercial production of transgenic animals.

\section{Acknowledgements}

This work was supported by grants from Jilin Province Science and Technology Innovation Project (2010) for Overseas Returnees and National Transgenic Animal Program (No. 2013ZX08007002-003) and Program for Changjiang Scholars and Innovative Research Team in University (No. IRT1248) in China.

\section{References}

1 Damude HG, Zhang H, Farrall L, Ripp KG, Tomb JF, Hollerbach D, Yadav NS: Identification of bifunctional delta12/omega3 fatty acid desaturases for improving the ratio of omega3 to omega6 fatty acids in microbes and plants. Proc Natl Acad Sci USA 2006;103:9446-9451.

- Satouchi K, Hirano K, Sakaguchi M, Takehara H, Matsuura F: Phospholipids from the free-living nematode caenorhabditis elegans. Lipids 1993;28:837-840.

3 Spychalla JP, Kinney AJ, Browse J: Identification of an animal omega-3 fatty acid desaturase by heterologous expression in arabidopsis. Proc Natl Acad Sci USA 1997;94:1142-1147.

4 Watts JL, Phillips E, Griffing KR, Browse J: Deficiencies in c20 polyunsaturated fatty acids cause behavioral and developmental defects in caenorhabditis elegans fat-3 mutants. Genetics 2003;163:581-589.

-5 Gvozdjáková A, Pella D, Kucharská J, Otsuka K, Singh RB: Omega-3-pufa, omega-6-pufa and mitochondria mitochondrial medicine; in Gvozdjáková A (ed). Springer Netherlands, 2008, pp 343-356.

6 Goodnight SJ, Harris W, Connor W: The effects of dietary omega 3 fatty acids on platelet composition and function in man: A prospective, controlled study. Blood 1981;58:880-885. 


\section{Cellular Physiology Cell Physiol Biochem 2013;32:523-532 and Biochemistry

7 Jump DB: The biochemistry of n-3 polyunsaturated fatty acids. J Biol Chem 2002;277:8755-8758.

8 Riediger ND, Othman RA, Suh M, Moghadasian MH: A systemic review of the roles of n-3 fatty acids in health and disease. J Am Diet Assoc 2009;109:668-679.

-9 Watts JL, Browse J: Genetic dissection of polyunsaturated fatty acid synthesis in caenorhabditis elegans. Proc Natl Acad Sci USA 2002;99:5854-5859.

10 Saeki K, Matsumoto K, Kinoshita M, Suzuki I, Tasaka Y, Kano K, Taguchi Y, Mikami K, Hirabayashi M, Kashiwazaki N, Hosoi Y, Murata N, Iritani A: Functional expression of a delta12 fatty acid desaturase gene from spinach in transgenic pigs. Proc Natl Acad Sci USA 2004;101:6361-6366.

$\checkmark 11$ Kang JX, Wang J, Wu L, Kang ZB: Transgenic mice: Fat-1 mice convert n-6 to n-3 fatty acids. Nature 2004;427:504-504.

12 Kao BT, Lewis KA, DePeters EJ, Van Eenennaam AL: Endogenous production and elevated levels of longchain n-3 fatty acids in the milk of transgenic mice. J Dairy Sci 2006;89:3195-3201.

13 Bongiovanni KD, Depeters EJ, Van Eenennaam AL: Neonatal growth rate and development of mice raised on milk transgenically enriched with omega-3 fatty acids. Pediatr Res 2007;62:412-416.

14 Lai L, Kang JX, Li R, Wang J, Witt WT, Yong HY, Hao Y, Wax DM, Murphy CN, Rieke A, Samuel M, Linville ML, Korte SW, Evans RW, Starzl TE, Prather RS, Dai Y: Generation of cloned transgenic pigs rich in omega-3 fatty acids. Nat Biotechnol 2006;24:435-436.

15 Wu X, Ouyang H, Duan B, Pang D, Zhang L, Yuan T, Xue L, Ni D, Cheng L, Dong S, Wei Z, Li L, Yu M, Sun QY, Chen DY, Lai L, Dai Y, Li GP: Production of cloned transgenic cow expressing omega-3 fatty acids. Transgenic Res 2012;21:537-543.

16 Morimoto KC, Van Eenennaam AL, DePeters EJ, Medrano JF: Endogenous production of n-3 and n-6 fatty acids in mammalian cells. J Dairy Sci 2005;88:1142-1146.

17 Tao F, Zhu SW, Fan J, Cheng BJ: Cloning and sequence analysis of maize fad2 gene. Zhi Wu Sheng Li Yu Fen Zi Sheng Wu Xue Xue Bao 2006;32:649-656.

18 Indo Y, Tatemizo A, Abe Y, Suzuki I, Matsumoto K, Hosoi Y, Kinoshita M, Mikami K, Murata N, Iritani A, Saeki K: Functional expression of a humanized gene for an omega-3 fatty acid desaturase from scarlet flax in transfected bovine adipocytes and bovine embryos cloned from the cells. Biochim Biophys Acta 2009;1791:183-190.

19 Kang JX, Wang J: A simplified method for analysis of polyunsaturated fatty acids. BMC Biochem 2005;6:5.

20 Pillai M, Venkataraman G, Kosak S, Torok-Storb B: Integration site analysis in transgenic mice by thermal asymmetric interlaced (tail)-pcr: Segregating multiple-integrant founder lines and determining zygosity. Transgenic Res 2008;17:749-754.

21 Park SH, Kim JN, Park TS, Lee SD, Kim TH, Han BK, Han JY: Cpg methylation modulates tissue-specific expression of a transgene in chickens. Theriogenology 2010;74:805-816.e801.

22 Simopoulos AP: The omega-6/omega-3 fatty acid ratio, genetic variation, and cardiovascular disease. Asia Pac J Clin Nutr 2008;17:S131-134.

23 Madsen L, Pedersen LM, Liaset B, Ma T, Petersen RK, van den Berg S, Pan J, Müller-Decker K, Dülsner ED, Kleemann R, Kooistra T, Døskeland SO, Kristiansen K: Camp-dependent signaling regulates the adipogenic effect of n-6 polyunsaturated fatty acids. J Biol Chem 2008;283:7196-7205.

-24 Kang ZB, Ge Y, Chen Z, Cluette-Brown J, Laposata M, Leaf A, Kang JX: Adenoviral gene transfer of caenorhabditis elegans n--3 fatty acid desaturase optimizes fatty acid composition in mammalian cells. Proc Natl Acad Sci USA 2001;98:4050-4054.

25 Chen Q, Liu Q, Wu Z, Wang Z, Gou K: Generation of fad2 transgenic mice that produce omega-6 fatty acids. Sci China C Life Sci 2009;52:1048-1054.

-26 Almendingen K, Höstmark AT, Fausa O, Mosdöl A, Aabakken L, Vatn MH: Familial adenomatous polyposis patients have high levels of arachidonic acid and docosahexaenoic acid and low levels of linoleic acid and $\alpha$-linolenic acid in serum phospholipids. Int J Cancer 2007;120:632-637.

-27 Chang ET, Bälter KM, Torrång A, Smedby KE, Melbye M, Sundström C, Glimelius B, Adami H-0: Nutrient intake and risk of non-hodgkin's lymphoma. Am J Epidemiol 2006;164:1222-1232.

28 Reyes N, Reyes I, Tiwari R, Geliebter J: Effect of linoleic acid on proliferation and gene expression in the breast cancer cell line t47d. Cancer Lett 2004;209:25-35.

29 Kilian M, Mautsch I, Gregor JI, Stahlknecht P, Jacobi CA, Schimke I, Guski H, Wenger FA: Influence of conjugated vs. Conventional linoleic acid on liver metastasis and hepatic lipidperoxidation in bop-induced pancreatic cancer in syrian hamster. Prostaglandins Leukot Essent Fatty Acids 2002;67:223-228. 
30 Zhu G, Chen H, Wu X, Zhou Y, Lu J, Deng J: A modified n-3 fatty acid desaturase gene from caenorhabditis briggsae produced high proportion of dha and dpa in transgenic mice. Transgenic Res 2008;17:717-725.

-31 Jia Q, Lupton JR, Smith R, Weeks BR, Callaway E, Davidson LA, Kim W, Fan Y-Y, Yang P, Newman RA, Kang JX, McMurray DN, Chapkin RS: Reduced colitis-associated colon cancer in fat-1 (n-3 fatty acid desaturase) transgenic mice. Cancer Res 2008;68:3985-3991.

-32 Nowak J, Weylandt KH, Habbel P, Wang J, Dignass A, Glickman JN, Kang JX: Colitis-associated colon tumorigenesis is suppressed in transgenic mice rich in endogenous n-3 fatty acids. Carcinogenesis 2007;28:1991-1995.

-33 Hudert CA, Weylandt KH, Lu Y, Wang J, Hong S, Dignass A, Serhan CN, Kang JX: Transgenic mice rich in endogenous omega-3 fatty acids are protected from colitis. Proc Natl Acad Sci USA 2006;103:11276-11281.

34 Xia S, Lu Y, Wang J, He C, Hong S, Serhan CN, Kang JX: Melanoma growth is reduced in fat-1 transgenic mice: Impact of omega-6/omega-3 essential fatty acids. Proc Natl Acad Sci USA 2006;103:12499-12504.

-35 Connor KM, SanGiovanni JP, Lofqvist C, Aderman CM, Chen J, Higuchi A, Hong S, Pravda EA, Majchrzak S, Carper D, Hellstrom A, Kang JX, Chew EY, Salem N, Serhan CN, Smith LEH: Increased dietary intake of [omega]-3-polyunsaturated fatty acids reduces pathological retinal angiogenesis. Nat Med 2007;13:868873.

-36 Marszalek JR, Lodish HF: Docosahexaenoic acid, fatty acid-interacting proteins, and neuronal function: Breastmilk and fish are good for you. Annu Rev Cell Dev Biol 2005;21:633-657. 